\title{
ANALISIS PENERAPAN OPERATING LEASE BERDASARKAN PSAK. NO 30 PADA PT. YOSEPHA MANOKWARI
}

\author{
Tifani Jones ${ }^{1}$, Sifrid. S. Pengemanan ${ }^{2}$ Steven. J. Tangkuman ${ }^{3}$ \\ 1,2,3 Jurusan Akuntansi, Fakultas Ekonomi dan Bisnis, Universitas Sam Ratulangi, Jl. Kampus Bahu, Manado, \\ 95115, Indonesia \\ E-mail : Tifani_Br@Yahoo.com
}

\begin{abstract}
PT. Yosepha is a company engaged in the services of contractors and suppliers who also have additional business to support the company and increase profits are rental of fixed assets. Type of lease applied by PT. Yosepha is an operating lease. Operating lease is an ordinary lease, whereby at the end of the lease term there is no option rights for the lessee or heavy equipment leased to remain owned by PT.Yosepha. In the lease activities conducted by PT.Yosepha must comply with the applicable accounting standards set out in statement of financial accounting standards number 30, because it is very impact on the financial statements generated by PT.Yosepha. The purpose of this study is to determine whether the application of lease accounting on PT.Yosepha has been in accordance with the statement of financial accounting standards number 30 and how the effect on the financial statements. The method used in this research is descriptive study. The result of the research is where PT.Yosepha has not totally applied lease accounting in this case that is operating lease in accordance with statement of financial accounting standards number 30 because there is a mistake in the disclosure and reporting so that the resulting financial statements are not clear so that it is not in accordance with applicable standards
\end{abstract}

Keywords: Operating Lease, Statement of Financial Accounting Standards Number 30, Financial Statement

\section{PENDAHULUAN}

Beberapa tahun terakhir terdapat peningkatan dalam pembangunan di daerah-daerah di berbagai pelosok di Indonesia tak terkecuali Indonesia bagian Timur. Pertumbuhan tahun ini tidak bisa lepas dari pembangunan infrastruktur oleh pemerintah, oleh sebab itu industri pembiayaan pun ikut berpesta, seperti yang terjadi dalam beberapa tahun belakangan ini. penjualan kendaraan untuk sektor pertambangan dan alat berat sudah mulai merangkak. Secara otomatis kondisi ini membuat pembiayaan alat berat terus meningkat kearah yang lebih baik dan membuat adanya peluang bagi perusahaan yang bergerak dibidang pembiayaan seperti leasing. Berdasarkan data OJK bulan September 2017/kuartal III 2017, total aset industri pembiayaan mengalami peningkatan sebesar 7,73\% menjadi Rp 468,11 Triliun. Sekedar gambaran, pada September 2016, total aset industri perusahaan pembiayaan tercatat Rp434,52 Triliun, turun 2,19 persen dibandingkan periode tahun 2015 yang mencapai Rp444,27 Triliun.

Pertumbuhan perusahaan yang bergerak di bidang pembiayaan ini sangat berdampak positif terutama bagi perusahaan leasing dan perusahaan yang memiliki kendala untuk mengembangkan usahanya atau untuk menambah jumlah aset tetap yang dibutuhkan di perusahaan. Leasing merupakan perjanjian kontraktual antara lessor dan lessee yang memberi hak kepada lessee untuk menggunakan aset tertentu yang dimiliki oleh lessor selama periode waktu tertentu dengan memberikan imbalan berupa pembayaran tunai yang biasanya secara periodik (Kieso dan Weygant, 2016 : 1121). Leasing merupakan salah satu alternatif yang dipilih perusahaan yang kurang modal atau ingin menghemat pemakaian tanpa harus 
kehilangan kesempatan untuk melakukan investasi kembali dalam sektor ekonomi tertentu yang dianggap produktif.

Dalam standar akuntansi keuangan terdapat dua kriteria leasing yaitu finance lease dan operating lease. Finance lease merupakan kegiatan sewa dengan pengalihan hak atas kepemilikan aset tetap yang disewa dari lessor ke lessee pada akhir masa sewa dan kontraknya mengikat sedangkan, operating lease tidak ada perpindahan kepemilikan atas aset tetap yang disewa. Standar akuntansi yang mengatur mengenai sewa (leasing) yaitu PSAK.No 30 dimana mengatur tentang kriteria pengelompokan transaksi sewa, perlakuan akuntansi untuk lessor dan untuk lessee serta pelaporan dan pengungkapan transaksi sewa oleh lessor dan lessee. Namun, masih tedapat kekeliruan dalam perlakuan serta pelaporan dan transaksi sewa hal tersebut karena kurangnya pengetahuan akan perkembangan standar akuntansi yang berlaku. Hal tersebut berdampak buruk bagi perusahaan terutama dalam pelaporan keuangan yang memiliki tujuan yaitu untuk memberikan informasi yang berguna bagi investor dan kreditur dalam pengambilan keputusan investasi dan kredit (Hery, 2017 : 40). Oleh karena itu perusahaan harus benar-benar paham akan penerapan transaksi sewa atau leasing yang benar dan sesuai dengan ruang lingkup dan karakteristiknya dalam laporan keuangan, sehingga perusahaan harus mengacu pada standar akuntansi keuangan yang berlaku yaitu, PSAK. No 30.

\section{TINJAUAN PUSTAKA}

\subsection{Pengertian Leasing}

Diana dan Setiawati (2017 : 399) sewa atau leasing adalah perjanjian kontrak antara lessor dan lessee dimana lessor memberikan hak kepada lessee untuk menggunakan aset tertentu milik lessor selama periode waktu yang disepakati sebagai imbalannya, lessee melakukan pembayaran sewa kepada lessor.

\subsection{Pihak- Pihak Terkait Dalam Leasing}

Adapun pihak-pihak yang terlibat dalam proses pemberian fasilitas leasing adalah sebagai berikut :

1. Lessor

Lessor merupakan perusahaan leasing yang memberikan jasa pembiayaan lessee dalam bentuk barang modal.

2. Lessee

Lessee merupakan pihak yang mendapat pembiayaan dalam bentuk barang atau modal dari lessor.

3. Supplier

Supplier merupakan perusahaan yang menyediakan barang untuk dijual kepada lessee dengan pembayaran secara tunai oleh lessor.

4. Bank

Dalam mekanisme leverage lease di mana sumber dana pembiayaan lessor didapat dengan cara kredit bank.

\subsection{Jenis- Jenis Perusahaan Leasing}

Menurut Kasmir (2014 : 244) jenis-jenis perusahaan leasing dalam menjalankan kegiatannya dibagi ke dalam tiga kelompok, yaitu:

\section{Independent Leasing}

Merupakan perusahaan leasing yang berdiri sendiri dapat sekaligus menjadi supplier atau bisa juga membeli -barang dari supplier untuk disewakan

2. Captive Lessor

Dalam perusahaan leasing jenis ini, produsen atau supplier mendirikan perusahaan leasing dan yang mereka lease adalah barang-barang milik mereka sendiri. Tujuan utamanya penumpukan barang di gudang 
3. Lease Broker

Perusahaan yang kerjanya hanya mempertemukan keinginan lessee kepada pihak lessor. Jadi dalam hal ini lease broker hanya sebagai perantara untuk mempertemukan atara lessor dengan lessee.

\subsection{Jenis- Jenis Leasing}

1. Finance Lease (Sewa Pembiayaan)

Sewa Pembiayaan (finance lease) menurut PSAK.No 30 Paragraf 8 Revisi 2011 adalah sewa yang mengalihkan secara substansial seluruh risiko dan manfaat yang terkait dengan kepemilikan suatu aset. Hak kepemilikin dialihkan, dapat juga tidak dialihkan.

2. Operating Lease (Sewa Biasa)

Menurut PSAK.No 30 Revisi 2011 Paragraf 8, sewa operasi (operating lease) yaitu sewa yang tidak memindahkan secara substansial keseluruhan risiko dan manfaat terkait dengan kepemilikan aset.

3. Sales-type Lease (sewa penjualan)

Sewa jenis ini merupakan transaksi pembiayaan sewa secara langsung (direct finance lease) dimana dalam jumlah transaksi termasuk laba yang diperhitungkan oleh pabrikan atau penyalur yang juga merupakan perusahaan sewa.

4. Leverage Lease

Transakasi sewa jenis ini melibatkan tiga pihak, yaitu lessee, lessor, dan credit provider yang membiayai bagian terbesar dari transaksi sewa. Lessor hanya membiayai $20 \%$ sampai dengan $40 \%$, sedangkan sisanya dibiayai pihak ketiga.

5. Direct Finance Lease

Transaksi sewa jenis ini terjadi jika lessee tidak pernah mendapatkan barang yang dijadikan sebagai objek lease, bisa dikatakan bahwa lessor membeli suatu barang atas permintaan lessee dan akan dipergunakan oleh lessee

\subsection{PSAK No.30 Tentang Sewa}

\subsubsection{Perlakuan Akuntansi Untuk Lessor}

Perlakuan akuntansi untuk lessor (Perusahaan sewa) berdasarkan PSAK.No 30 dibagi menurut jenis sewa yaitu :

\section{Operating Lease}

1. Aset untuk sewa operasi disajikan oleh lessor di neraca berdasarkan sifat aset tersebut

2. Pendapatan atas sewa diakui sebagai pendapatan, kecuali terdapat dasar sistemastis yang lebih menggambarkan dimana manfaat penggunaan aset menurun

3. Biaya awal langsung dikeluarkan lessor kemudian ditambahkan ke jumlah tercatat aset sewaan dan diakui sebagai beban selama masa sewa dengan dasar yang sama dengan pendapatan sewa

4. Metode penyusutan untuk suatu aset sewa diterapkan secara konsisten dan dihitung berdasarkan PSAK 16 dan PSAK 19

5. Jumlah agregat pembayaran sewa minimum dimasa depan dalam sewa operasi yang tidak dapat dibatalkan untuk setiap periode berikut

6. Total rental kontijen yang diakui sebagai penghasilan dalam periode berjalan

\section{Finance Lease}

1. Penanaman neto untuk aset yang disewakan harus dicatat dan diperlakukan sebagai penanaman neto sewa. Total penanaman neto terdiri atas total piutang sewa ditambah nilai sisa yang akan diterima pada masa akhir sewa kemudian dikurangi dengan pendapatan sewa yang belum diakui dan simpanan jaminan.

2. Selisih antara piutang atas sewa ditambahkan dengan nilai sisa dengan harga perolehan aset yang disewa diperlakukan sebagai pendapatan sewa yang belum diakui.

3. Bila perusahaan menjual barang modal kepada penyewa sebelum berakhirnya masa sewa, maka perbedaan antara harga jual dengan penanaman neto dalam sewa pada saat 
penjualan dilakukan harus diakui dan dicatat sebagai keuntungan atau kerugian periode berjalan.

4. Pendapatan lain yang diperoleh yang berhubungan dengan transaksi sewa harus diakui dan dicatat sebagai pendapatan atas periode berjalan.

5. Pendapatan sewa yang belum diakui harus dialokasikan secara konsisten atas pendapatan sewa berdasarkan tingkat pengendalian.

\subsubsection{Pelaporan dan Pengungkapan Transaksi Operating Lease oleh Lessor}

1. Barang modal yang disewakan dilaporkan berdasarkan harga perolehan setelah dikurangi dengan akumulasi penyusutannya.

2. Aset yang disewakan dilaporkan secara terpisah dari aset tetap yang tidak disewakan.

3. Untuk perhitungan pada laporan rugi laba, jumlah pendapatan dilaporkan terpisah dari kelompok biaya

4. Pendapatan sewa harus dilaporkan sebagai komponen utama dalam kelompok pendapatan.

5. Penyusutan untuk aset yang disewakan dilaporkan secara terpisah dari penyusutan aset yang tidak disewakan .

6. Hal- hal berikut harus dicantumkan pada catatan atas laporan keuangan:

1.Kebijakan akuntansi sehubungan dengan transaksi sewa.

2.Jumlah pembayaran sewa minimal untuk 2 tahun berikutnya.

3.Sifat dari simpanan jaminan (jika ada)

4.Aset yang disewakan yang dijaminkan kepada pihak ketiga.

5.Sewa sindikasi dan leveraged leases.

\subsection{PSAK.No 16 Tentang Aset Tetap}

\subsubsection{Penyusutan Aset Tetap}

Penyusutan yaitu alokasi secara sistematis jumlah yang dapat disusutkan pada suatu aset selama umur manfaatnya. Kehilangan kapasitas produksi ini diakui sebagai beban depresiasi. Perlakuan atas penyusutan aset tetap menurut PSAK.No 16 yaitu:

1. Setiap aset tetap yang memilki biaya perolehan yang cukup signifikan terhadap jumlah biaya perolehan seluruh aset harus disusutkan terpisah.

2. Untuk beban penyusutan untuk setiap periode harus diakui dalam laporan rugi laba namun ada pengecualian jika beban tersebut dimasukkan dalam jumlah tercatat aset lain.

3. Penyusutan aset dimulai pada saat aset tersebut siap digunakan.

4. Penyusutan aset dapat dihentikan lebih awal jika : (1) Aset tersebut diklasifikasikan sebagai aset yang dimiliki untuk dijual; dan (2) Pengakuan terhadap aset dihentikan.

5. Bangunan dan tanah diperlakukan sebagai aset terpisah walaupun diperoleh sekaligus.

6. Nilai residu dan umur manfaat suatu aset harus di-review minimum setiap akhir tahun buku.

7. Metode penyusutan yang dapat digunakan yaitu : metode garis lurus, metode saldo menurun, metode jumlah unit.

8. Seluruh faktor berikut diperhitungkan dalam menentukan umur manfaat suatu aset: (1) Perkiraan daya pakai; (2) Perkiraan tingkat keausan fisik; (3) Keusangan teknis atau keusangan komersial; dan (4) Pembatasan hukum atau yang serupa.

\subsection{Penelitian Terdahulu}

Idrus (2016), Penerapan PSAK.No 30 tentang leasing aktiva tetap pada PT. Bumi

Beton, penelitian ini juga membahas mengenai penerapan PSAK.No 30 tentang leasing, namun lebih difokuskan pada pencatatan transaksi dalam leasing dan penyusutan aktiva tetap secara lebih detail, jenis leasing yang diteliti yaitu capital lease serta menggunakan metode dan objek penelitian yang berbeda. Yanti (2013), Analisis akuntansi leasing pada PT. Puri Green Resources Pekanbaru, penelitian ini membahas mengenai akuntansi leasing, perbedaannya yaitu perlakuan akutansi leasing yang dibahas yaitu dari pihak lessee, jenis 
leasing yang diteliti yaitu capital lease, serta membahas pencatatan transaksi leasing dari pihak lessee dan objek penelitian yang berbeda.

\section{METODE PENELITIAN}

\subsection{Jenis Penelitian}

Jenis Penelitian yang digunakan adalah deskriptif kualitatif yaitu penelitian dengan menganalisa dan kemudian menggambarkan masalah atau fenomena yang diteliti. Mudrajad Kuncoro (2014 : 12) Penelitian deskriptif meliputi pengumpulan data untuk diuji hipotesis atau menjawab pertanyaan mengenai status terakhir dari subjek penelitian paling umum meliputi penilaian sikap atau pendapat terhadap individu, keadaan, dan organisasi.

\subsection{Waktu dan Tempat Penelitian}

Penelitian ini mulai dilaksanakan pada 19 Maret 2018 sampai dengan 5 April 2018 di

PT. Manokwari yang berlokasi di Jalan. Trikora, Sowi 2, Manokwari, Papua Barat.

\subsection{Teknik Pengumpulan Data}

1. Metode observasi yaitu melakukan pengamatan terhadap gejala yang tampak pada objek penelitian.

2. Metode wawancara. yaitu melakukan tanya jawab dengan kepala pimpinan dan bagian prosedur perjanjian leasing serta pihak-pihak yang terkait .

3. Studi kepustakaan melakukan telaah atas data- data diperoleh melalui berbagai sumber meliputi jurnal ilmiah, buku-buku, karya ilmiah dll.

4. Dokumentasi merupakan teknik pengumpulan data dengan melihat secara langsung dokumen, catatan-catatan dan buku-buku yang digunakan perusahaan.

\subsection{Metode Analisis Data}

Dalam melakukan analisis data, pada penelitian ini penulis berencana menggunakan kerangka pemikiran sebagai berikut:

1. Melihat gambaran umum PT.Yosepha yang berupa riwayat singkat perusahaan dan struktur organisasi dan pembagian tugas PT. Yosepha

2. Mengumpulkan dan memeriksa dokumen perjanjian sewa PT. Yosepha

3. Mengidentifikasi pencatatan setiap transaksi leasing yang dibuat oleh PT.Yosepha khususnya pencatatan untuk transaksi sewa.

4. Memeriksa laporan keuangan selama periode leasing atas pelaporan pencatatan aset tetap yang disewakan.

\section{HASIL PENELITIAN}

\subsection{Hasil Analisis dan Pembahasan}

\subsubsection{Perlakuan Akuntansi Leasing pada PT. Yosepha}

PT. Yosepha merupakan perusahaan jasa kontraktor dan leveransir dan juga menyediakan jasa sewa aset tetap dalam hal ini yaitu alat berat. Alat berat yang dimiliki oleh PT. Yosepha sebagai berikut :

\begin{tabular}{|l|l|l|l|}
\hline NO. & \multicolumn{1}{|c|}{ NAMA ALAT } & \multicolumn{1}{|c|}{$\begin{array}{c}\text { Harga Perbulan } \\
\text { 207 Jam/26 Hari }\end{array}$} & \multicolumn{1}{|c|}{$\begin{array}{c}\text { Sewa Perhari } \\
\text { 8 Jam/ Hari }\end{array}$} \\
\hline 1. & Bulldozer & Rp. 180.000 .000 & Rp. 10.000 .000$. \\
\hline 2. & Excavator & Rp. 120.000 .000 & Rp. 7.200 .000 \\
\hline 3. & Greder & Rp. 80.000 .000 & Rp. 4.000 .000 \\
\hline 4. & Bomag/Vibro & Rp. 70.000 .000 & Rp. 4.032 .000 \\
\hline 5. & Loader & Rp. 80.000 .000 & Rp. 4.120 .000 \\
\hline 6. & Finisher & Rp. 110.000 .000 & Rp. 4.816 .000 \\
\hline 7. & Tire Roller & Rp. 110.000 .000 & Rp. 5.600.000 \\
\hline 8. & Nissan + Fuso & Rp 30.000.000 & Rp. 1.000 .000 \\
\hline 9. & PS 120/ PS 100/ PS 115/ Dustro & Rp. 18.000 .000 & Rp. 600.000 \\
\hline 10. & Toronton & Rp. $300.000 / \mathrm{Km}$ & \\
\hline
\end{tabular}


Perjanjian yang dibuat oleh PT.Yosepha dalam sewa sebagai berikut :

1. Penyewa harus mengisi dan melengkapi berkas yang diperlukan serta menandatangani surat perjanjian atau kontrak.

2. Penyewa (lessee) harus membayar DP sebanyak 30\% dari harga sewa alat berat.

3. Penyewa (lessee) bertanggung jawab atas : mobilisasi dan demobillisasi, oli, BBM, service rutin, retasi, ban, tambal ban, dan spare part dan kerusakan dilapangan.

4. Apabila alat berat yang disewakan rusak karena pemaksaan atas perkerjaan maka akan ditagihkan.

\title{
4.1.2. Pelaporan dan Pengungkapan Transaksi Sewa PT. Yosepha
}

\author{
PT.YOSEPHA \\ NERACA
}

PER 31 DESEMBER 2016

\begin{tabular}{|c|c|c|c|}
\hline ASET & & KEWAJIBAN & \\
\hline ASET LANCAR & & KEWAJIBAN LANCAR & \\
\hline KAS DAN SETARA & Rp $20,200,330,712$ & HUTANG BANK & $\operatorname{Rp} 28,200,630,000$ \\
\hline KAS & Rp $12,050,352,500$ & HUTANG USAHA & Rp 7,306,403,800 \\
\hline PIUTANG USAHA & & & \\
\hline JUMLAH ASET & $\underline{\mathrm{RP}} \quad 32,250,683,212$ & KEWAJIBAN & $\underline{\mathrm{Rp}} 35,507,033,800$ \\
\hline LANCAR & & LANCAR & \\
\hline ASET TETAP & & MODAL & \\
\hline ASET TETAP & & & \\
\hline HARGAPEROLEHAN & Rp $32,157,099,042$ & MODAL & $3,187,098,390$ \\
\hline AKM PENYUSUTAN & $\operatorname{Rp} \quad 6,456,488,832$ & AKM.LABA/RUGI TAHUN & $3,850,670,246$ \\
\hline & & LALU & $1,502,831,776$ \\
\hline & & LABA RUGI TAHUN & \\
\hline $\begin{array}{l}\text { JUMLAH } \quad \text { ASET } \\
\text { TETAP }\end{array}$ & $\underline{\mathrm{Rp} \quad 25,700,610,210}$ & $\begin{array}{l}\text { BERJALAN } \\
\text { JUMLAH MODAL }\end{array}$ & $\underline{\mathrm{Rp}} 38,540,600,412$ \\
\hline ASET LAIN LAIN & Rp 20,140,051,958 & & \\
\hline HARGA & $\mathrm{Rp} \quad 4,043,711,168$ & & \\
\hline PEROLEHAN & $\underline{\mathrm{Rp}} 16,096,340,790$ & & \\
\hline AKM PENYUSUTAN & & & \\
\hline $\begin{array}{l}\text { TOTAL ASET LAIN- } \\
\text { LAIN }\end{array}$ & & & \\
\hline TOTAL ASET & $\underline{\mathrm{Rp} \quad 74,047,634,212}$ & $\begin{array}{l}\text { TOTAL KEWAJIBAN DAN } \\
\text { MODAL }\end{array}$ & $\underline{\mathrm{Rp}} \quad 74,047,634,212$ \\
\hline
\end{tabular}

Sumber : Data Olahan

Neraca PT. Yosepha menunjukkan bahwa jumlah aset tetap yang dimiliki oleh PT.Yosepha sampai 31 Desember 2016 yaitu sebesar Rp.25.700.610.210 dan merupakan total keseluruhan dari semua aset yang dimiliki perusahaan baik yang disewakan dan tidak disewakan dan sudah termasuk dengan pengurangan akumulasi penyusutan alat berat tersebut. 


\section{PT. YOSEPHA}

LAPORAN LABA RUGI

UNTUK PERIODE YANG BERAKHIR PADA 31 DESEMBER 2016

\begin{tabular}{|c|c|c|}
\hline \multirow{2}{*}{\multicolumn{2}{|c|}{$\begin{array}{l}\text { PENDAPATAN } \\
\text { BIAYA OPERASIONAL DAN UMUM }\end{array}$}} & $\operatorname{Rp} 5,400,512,000$ \\
\hline & & \\
\hline BIAYA GAJI KARYAWAN & Rp $1,250,000,050$ & \\
\hline BIAYA UTILITY & Rp 42,039,729 & \\
\hline BIAYA PEMELIHARAAN & $\mathrm{Rp} \quad 20,700,200$ & \\
\hline BIAYA PENYUSUTAN & Rp 2,384,520,031 & \\
\hline BIAYA UMUM DAN ADM LAIN & $\operatorname{Rp} 25,706,300$ & \\
\hline BIAYA LAIN-LAIN & Rp $15,958,800$ & \\
\hline TOTAL & & $\underline{\mathrm{Rp} 3,738,925,110}$ \\
\hline LABA OPERASI & & $\overline{\mathrm{Rp} 1,661,586,890}$ \\
\hline \multicolumn{3}{|l|}{ PENDAPATAN (BIAYA) LAIN- LAIN } \\
\hline JASA GIRO & $\operatorname{Rp} 5,535,932$ & \\
\hline BIAYA ADMINISTRASI BANK & $\operatorname{Rp}(1,168,500)$ & \\
\hline PAJAK GIRO & $\underline{\operatorname{Rp}(1,107.186)}$ & $3,260,246$ \\
\hline LABA BERSIH SEBELUM PAJAK & & $\mathrm{Rp} \quad 1.664 .847 .136$ \\
\hline PAJAK PENGHASILAN & & $\underline{\mathrm{Rp}} \quad 162,015,360$ \\
\hline LABA BERSIH SETELAH PAJAK & & $\underline{\mathrm{Rp}} 1.502 .831 .776$ \\
\hline
\end{tabular}

Sumber : Data Olahan

Perusahaan menggunakan metode penyusutan garis lurus untuk menghitung penyusutan aset tetap yang disewakan yang dilakukan rutin pada akhir tahun sebelum tutup buku. Penyusutan pada 31 Desember 2016 yaitu sebesar Rp. 2.384.520.031 merupakan jumlah keseluruhan antara penyusutan aset tetap yang disewakan dan yang tidak disewakan.

\subsection{Pembahasan}

Sewa yang dilakukan oleh PT.Yosepha yaitu sewa operasi (operating lease) yang dimana menurut PSAK No.30 bahwa pengungkapan dan pelaporan yang dicantumkan atas laporan keuangan yaitu :

1. Barang modal yang disewakan dilaporkan dengan berdasarkan harga perolehan setelah dikurangi dengan akumulasi penyusutannya.

2. Perhitungan rugi laba harus disusun sedemikian rupa sehingga seluruh pendapatan dilaporkan dalam kelompok yang terpisah dari kelompok biaya (single step).

3. Pendapatan sewa harus dilaporkan sebagai komponen utama dalam kelompok pendapatan.

4. Penyusutan untuk aset yang disewakan dilaporkan secara terpisah dari penyusutan aset yang tidak disewakan.

5. Pengungkapan yang layak harus dicantumkan dalam catatan atas laporan keuangan 


\subsubsection{Perbandingan Penerapan Operating Lease Berdasarkan PSAK.No 30 dan yang Diterapkan oleh PT.Yosepha}

\begin{tabular}{|l|l|c|}
\hline \multicolumn{1}{|c|}{ PSAK No.30 } & \multicolumn{1}{|c|}{ PT.Yosepha } & Kesesuaian \\
\hline $\begin{array}{l}\text { Biaya, termasuk biaya penyusutan } \\
\text { yang terjadi untuk memperoleh } \\
\text { pendapatan sewa diakui sebagai beban }\end{array}$ & $\begin{array}{l}\text { PT. Yosepha mengakui penyusutan aset } \\
\text { tetap sebagai beban }\end{array}$ & Sesuai \\
\hline $\begin{array}{l}\text { Pendapatan dari sewa operasi diakui } \\
\text { sebagai pendapatan dengan garis lurus } \\
\text { selama masa sewa }\end{array}$ & $\begin{array}{l}\text { PT. Yosepha mengakui mengakui } \\
\text { pendapatan dari sewa dengan dasar garis } \\
\text { lurus selama masa sewa }\end{array}$ & Sesuai \\
\hline $\begin{array}{l}\text { Penyusutan untuk aset sewa harus } \\
\text { konsisten sesuai dengan penyusutan } \\
\text { normal untuk aset yang sejenis, dan } \\
\text { dihitung sesuai PSAK. No.16 dan } \\
\text { PSAK 19 }\end{array}$ & $\begin{array}{l}\text { Penyusutan yang dilakukan PT.Yosepha } \\
\text { dilakukan secara konsisten pada akhir } \\
\text { tahun dengan metode yang sama yaitu } \\
\text { garis lurus. }\end{array}$ & Sesuai \\
\hline $\begin{array}{l}\text { Lessor menyajikan aset sewa untuk } \\
\text { sewa operasi di neraca sesuai sifat } \\
\text { aset tersebut }\end{array}$ & $\begin{array}{l}\text { PT.Yosepha belum memisahkan antara } \\
\text { aset yang disewakan dan yang tidak } \\
\text { disewakan dalam laporan posisi keuangan }\end{array}$ & Belum sesuai \\
\hline $\begin{array}{l}\text { Penyusutan untuk aset yang } \\
\text { disewakan dilaporkan secara terpisah } \\
\text { dari penyusutan aset yang tidak } \\
\text { disewakan }\end{array}$ & $\begin{array}{l}\text { PT.Yosepha tidak memisahkan } \\
\text { penyusutan aset yang disewakan dan } \\
\text { yang tidak }\end{array}$ & Belum sesuai \\
\hline $\begin{array}{l}\text { Aset yang disewakan dilaporkan } \\
\text { secara terpisah dari aset tetap yang } \\
\text { tidak disewakan. }\end{array}$ & $\begin{array}{l}\text { PT.Yosepha tidak memisahkan aset yang } \\
\text { disewakan dan yang tidak dalam } \\
\text { pelaporan }\end{array}$ & Belum sesuai \\
\hline
\end{tabular}

4.2.2. Penyajian Transaksi Sewa Dalam Laporan Keuangan Berdasarkan PSAK.No 30

PT. YOSEPHA

LAPORAN LABA RUGI

UNTUK PERIODE YANG BERAKHIR PADA 31 DESEMBER 2016

\author{
PENDAPATAN \\ BIAYA OPERASIONAL DAN UMUM \\ BIAYA GAJI KARYAWAN \\ BIAYA UTILITY \\ BIAYA PEMELIHARAAN \\ BIAYA PENYUSUTAN \\ BIAYA PENYUSUTAN ASET SEWA \\ BIAYA UMUM DAN ADM LAIN \\ BIAYA LAIN-LAIN \\ TOTAL \\ LABA OPERASI \\ PENDAPATAN (BIAYA) LAIN LAIN \\ JASA GIRO \\ BIAYA ADMINISTRASI BANK \\ PAJAK GIRO
}

LABA BERSIH SEBELUM PAJAK

PAJAK PENGHASILAN

\section{LABA BERSIH SETELAH PAJAK}

Sumber : Data Olahan
Rp 5,400,512,000

Rp 1,250,000,050

Rp 42,039,729

Rp 20,700,200

Rp 2,384,520,031

Rp 25,706,300

Rp $15,958,800$

$\underline{\operatorname{Rp} 3,738,925,110}$

Rp $1,661,586,890$

Rp 5,535,932

$\operatorname{Rp}(1,168,500)$

$\underline{\operatorname{Rp}(1,107,186)}$ \begin{tabular}{lr}
$\mathrm{Rp}$ & $3,260,246$ \\
\hline $\mathrm{Rp}$ & $1,664,847,136$ \\
$\mathrm{Rp}$ & $162,015,360$ \\
\hline $\mathrm{Rp}$ & $1,502,831,776$ \\
\hline
\end{tabular}

Sumber : Data Olahan 
Usulan tersebut tidak jauh berbeda dengan yang disajikan oleh PT.Yosepha hanya perlu adanya pemisahan antara penyusutan aset tetap yang disewakan dan yang tidak disewakan dan dihitung secara terpisah agar jumlah biaya operasional dapat diketahui secara jelas dan sesuai dengan ketentuan dalam PSAK.No 30 untuk pelaporan operating lease yaitu penyusutan untuk aset yang disewakan dilaporkan secara terpisah dari penyusutan aset yang tidak disewakan

\section{PT. YOSEPHA \\ NERACA \\ PER 31 DESEMBER 2016}

\section{ASET}

\section{ASET LANCAR \\ KAS DAN SETARA Rp 20,200,330,712 \\ KAS}

PIUTANG USAHA

JUMLAH ASET

LANCAR

ASET TETAP

ASET TETAP

HARGA PEROLEHAN

AKM PENYUSUTAN

ASET TETAP

DISEWAKAN -

HARGA PEROLEHAN

AKM.PENYUSUTAN

JUMLAH $\quad$ ASET $\quad \underline{R p ~ 25,700,610,210}$

TETAP

\section{ASET LAIN LAIN}

HARGA PEROLEHAN

AKM PENYUSUTAN

TOTAL ASET LAIN-

LAIN

TOTAL ASET

\section{$\underline{\mathrm{Rp} \quad 74,047.634 .212}$}

Rp $4,043,711,168$

$\underline{\mathrm{Rp} 16,096,340,790}$

$\begin{array}{lr}\text { Rp } & 32,157,099,042 \\ \operatorname{Rp} & 6,456,488,832\end{array}$

MODAL

AKM.LABA/RUGI TAHUN

LALU

LABA RUGI TAHUN

BERJALAN

JUMLAH MODAL
Rp 28,200,630,000

Rp 7,306,403,800

$\underline{\operatorname{Rp} 35,507,033,800}$

Rp $\quad 3,187,098,390$

Rp $3,850,670,246$

Rp $1,502,831,776$

$\underline{\mathrm{Rp} 38,540,600,412}$

Sumber : Data Olahan

TOTAL KEWAJIBAN DAN $\underline{\mathrm{Rp} \quad 74.047 .634 .212}$ MODAL

Usulan untuk neraca yang disajikan berdasarkan PSAK.No 30 yaitu ada pemisahan antara aset tetap yang disewakan dan yang tidak disewakan, agar dapat diketahui secara jelas berapa jumlah dari aset perusahaan yang disewakan dan yang tidak disewakan

\section{KESIMPULAN DAN SARAN}

\subsection{Kesimpulan}

Berdasarkan hasil penelitian yang telah dilakukan pada PT. Yosepha maka dapat disimpulkan bahwa penerapan akuntansi leasing pada PT.Yosepha belum sesuai dengan PSAK.No 30. Penerapan dan pelaporan akuntansi sewa aset tetap dengan cara sewa operasi (operating lease) berupa alat berat yang dilakukan oleh PT.Yosepha masih terdapat koreksi 
yaitu PT.Yosepha tidak memisahkan antara aset tetap dan aset tetap yang disewakan pada neraca dan juga tidak memisahkan antara beban penyusutan aset tetap yang disewakan dan yang tidak disewakan pada laporan rugi laba yang seharusnya dipisahkan dalam pelaporannya menurut PSAK.No 30.

\subsection{Saran}

Sebaiknya PT.Yosepha dalam kegiatan sewa yang dilakukan dalam hal ini bertindak sebagai lessor mengikuti dan menerapkan standar yang berlaku yaitu PSAK. No 30 yang mengatur mengenai sewa (lease) begitupun dalam penyajian laporan keuangan, serta mengikuti perkembangan standar akuntansi keuangan sehingga laporan keuangan tersebut wajar dan dapat dipahami oleh pengguna laporan keuangan yang berkepentingan.

\section{DAFTAR PUSTAKA}

Diana, Setiawati 2017. Akuntansi Keuangan Menengah Berdasarkan Standar Akuntansi Keuangan Terbaru. Andi. Yogyakarta

Hery. 2017. Teori Akuntansi Pendekatan Konsep dan Analisis. Grasindo. Jakarta

Idrus, Muhammad. 2016. Penerapan PSAK. No 30 Tentang Akuntansi Leasing Aset Tetap Pada PT.Bumi Beton. Fakultas Ekonomi. Universitas Negeri Makassar. Jurnal Imiah BONGAYA (Manajemen \& Akuntansi) April 2016, No.XIX.

Ikatan Akuntan Indonesia. 2011. Standar Akuntansi Keuangan No. 30 tentang Sewa, Jakarta. Ikatan Akuntan Indonesia (IAI). Standar Akuntansi Keuangan (SAK) Per 1 Januari 2015.

Izati, Nur. 2014. Analisis Akuntansi Sewa Berdasarkan PSAK NO.30 Pada PT.MAF-MCF Tanjung Pinang. Fakultas Ekonomi. Universitas Maritim Raja Ali Haji.

Kasmir. 2014. Bank dan Lembaga Keuangan Lainnya. Edisi Revisi, Cetakan keempat belas, PT. Raja Grafindo Persada, Jakarta.

Kieso, D. E., Weygandt, J. J., \& Warfield, T. D. 2016. Intermediate Accounting 16 Edition. Wiley. United States of America .

Ryabchenko. 2016. Topical Issues of Accounting of Leasing Transactions in Terms of International Financial Reporting Standards. Kuban State University. International Journal of Economics and Financial Issues. Vol 6 Issue 2

Yanti Rina. 2013. Analisis Akuntansi Leasing Pada PT. Puri Green Resources Pekanbaru. Politeknik Caltex Riau. Jurnal Akuntansi Keuangan dan Bisnis Vol.6. 